\title{
Analisis Reaksi Pasar Modal Pada Peristiwa Pemilihan Gubernur Dki Jakarta Tahun 2017
}

\author{
Ida Ayu Nirma Prameswari ${ }^{1}$ \\ Made Gede Wirakusuma ${ }^{2}$ \\ ${ }^{1}$ Fakultas Ekonomi dan Bisnis Universitas Udayana (Unud), Bali, Indonesia \\ email: nirmaprameswari@gmail.com/Telp: +62 82247973141 \\ ${ }^{2}$ Fakultas Ekonomi dan Bisnis Universitas Udayana (Unud), Bali, Indonesia
}

\begin{abstract}
ABSTRAK
Aktivitas investasi sangat erat kaitannya dengan kandungan informasi yang berpengaruhpada pasar modal.Investor sebelum melakukan keputusan investasinya akan sangat memperhatikan informasi dari beragam peristiwa, tidak terkecuali peristiwa non ekonomi seperti peristiwa politik. Tujuan penelitian ini untuk menjelaskan reaksi pasar modal atas peristiwa Pemilihan Gubernur DKI Jakarta Tahun 2017 dengan melihat abnormal return dan trading volume activity. Penelitian ini merupakan studi peristiwadengan sampel perusahaan tergabung dalam Indeks LQ-45 dan menggunakan 11 hari periode pengamatan. Metode sampling menggunakan teknik purposive sampling. Teknik analisis data yaitu dengan uji paired sample t-test. Penelitian ini memberikan hasiltidak terdapat perbedaan rata-rata abnormal return dan trading volume activity sebelum dan sesudah Pemilihan Gubernur DKI Jakarta Tahun 2017. Implikasi penelitian secara teoretis memberikan bukti empiris yang menguatkan teori kandungan informasi dan secara praktis dapat menjadi pertimbangan bagi investor agar lebih cermat menghadapi setiap peristiwa sebelum mengambil keputusan investasi di pasar modal.

Kata kunci: Event study, peristiwa politik, abnormal return, trading volume activity
\end{abstract}

\begin{abstract}
Investment activity is tightly related to information contents which can affect the capital market. Through investment decision making, investors will take concerned about information from various events, including politic events. This research purpose is to explain the capital market reaction regarding the Governor election of DKI Jakarta in 2017 by observing the abnormal return and trading volume activity. This is an event study research with the sample are companies engaged in Index LQ-45 and through 11 days observation. The sampling method used purposive sampling. Data analysis technique is paired sample t-test. The result shown there is no difference of average abnormal return and trading volume activity, both before and after the election. Implications of this research theoretically give empirical evidence which strengthen the information content theory and practically could be a consideration for the investors to be thriftier in facing various events whilst making investment decision in the capital market.
\end{abstract}

Keywords: Event study, politic events, abnormal return, trading volume activity 
Ida Ayu Nirma Prameswari dan Made Gede Wirakusuma. Analisis...

\section{PENDAHULUAN}

Pasar modal adalah tempat bagi investor yang ingin memanfaatkan sejumlah dana miliknya untukmemperoleh keuntungan melalui suatu risiko tersendiri. Pasar modal akan efisien bila harga instrumen keuangan yang diperjual-belikan memperlihatkan secara akurat nilai perusahaan termasuk prospek laba dan kualitas manajemennya. Apabila nilai perusahaan dan kualitas manajemennya diragukan oleh calon investor, maka hal ini akan tercermin pada harga saham dan surat berharga lainnya yang turun. Perkembangan dan kinerja pasar saham yang stabil akan menarik investasi dari investor dalam dan luar negeri dan memiliki pengaruh terhadap daya saing ekonomi negara secara keseluruhan (Levine \&Zervos, 1998).

Informasi merupakan hal penting yang tidak dapat dipisahkan dalam pasar modal. Investor akan menggunakan informasi untuk melakukan penilaian terhadap kinerja dan prospek perusahaan kedepannya termasuk sebagai pertimbangan dalam pengambilan keputusan bisnis. Investor juga memerlukan informasi guna memperoleh bayangan mengenai tingkat pengembalian (return) dan tingkat risiko yang akan diterima dari aktivitas inventasi yang dilakukan.

Tingkat pengembalian adalah hasil yang didapatkan dari investasi. Menurut Hartono (2014), return terdiri dari return sesungguhnya, yaitu return telah terjadi dan return ekspektasian merupakan returndi masa datang yang diinginkan oleh investor. Investor melakukan investasi dan pengambilan keputusan dengan melihat sekuritas pemberi return yang maksimal dan sesuai harapan. Selain return, yang mendapat pengaruh adalah volume perdagangkan saham. Volume 
perdagangan yaitu jumlah saham pada periode tertentu yang diperjual-belikan untuk menggerakkan harga saham (Sumiyana, 2007).

$$
\text { Investor dalam melakukan keputusan investasinya akan sangat }
$$
memperhatikan kandungan informasi yang dapat berasal dari beragam peristiwa. Peristiwa-peristiwa tersebut tidak hanya berasal dari peristiwa ekonomi, namun juga dari peristiwa non ekonomi. Suatu negara berkembang dapat terkena dampak melalui peristiwa domestik maupun internasional,seperti peristiwa politik dan ketidakseimbangan variabel makroekonomi berbahaya bagi perekonomian (Khalid \& Rajaguru, 2010). Permana (2013) menyatakan peristiwa ekonomi dapat berupa inflasi, kurs valas, coporate action, dll. Sedangkan peristiwa non ekonomi meliputi seperti isu-isu yang terjadi seputaran HAM, lingkungan sosial, maupun peristiwa politik lainnya. Semakin pentingfungsi pasar modal pada perekonomian suatu negara, maka terhadap peristiwa di sekitarnya yang sedang berlangsung pasar modal lebih sensitif (Widianingsih \& Wijaya, 2014).

Peristiwa non ekonomi terkadang bisa menjadi pemicu adanya reaksi pasar modal (Jatmiko et al., 2014). Informasi yang ditimbulkan akibat peristiwa tersebut dapat memberikan pengaruh pada aktivitas yang terjadi di pasar modal, sehingga acap kali para investor menggunakan informasi tersebut untuk mempertimbangkan keputusan investasinya.

Peristiwa non ekonomi yang kerap menjadi sebab kuat untuk memengaruhi iklim pasar modal adalah peristiwa politik. Hal ini dikarenakan pada dasarnya dinamika politik mempunyai kaitan dengankestabilanekonomi suatu negara (Wardhani, 2012). Politik yang stabil menguntungkan investorkarena 
Ida Ayu Nirma Prameswari dan Made Gede Wirakusuma. Analisis...

investor merasa kurang berisiko(Manzoor, 2013).Bechtel (2009) mengemukakan bahwa situasi politik yang stabil memiliki risiko investasi yang rendah dan sistematis untuk mendorong pertumbuhan, investasi modal dan meningkatkan kinerja ekonomi secara keseluruhan. Sementara, situasi politik yang tidak stabil dapat mengurangi investasi asing di pasar saham dan bisa menyebabkan investor enggan berinvestasi karena berada dalam kondisi politik yang lebih beragam (Chan \& John, 1996).

Beragam peristiwa politik yang terjadi seperti pergantian presiden, pemilihan umum kepala daerah/gubernur, maupun kerusuhan poltik lainnya akan memberikan dampak terhadap iklim investasi yang diharapkan oleh para investor, sehingga hal ini akan menimbulkan respon dari investor. Adanya stabilitas perekonomian yang dicerminkan dari stabilitas politik yang baik dari suatu negara, akan mempengaruhi rasa aman dan kepercayaan investor dalam melakukan aktivitas investasinya di pasar modal, sehingga selayaknya para investor akan menaruh ekspektasi atau harapannya atas peristiwa-peristiwa politik yang sedang berlangsung. Harapan dari para investor ini akan tercermin pada volume perdagangan saham maupun naik-turunnya harga saham di bursa efek.

Kasus pengaruh peristiwa politik yang berakibat pada sektor ekonomi khususnya pasar modal belakangan banyak terjadi di Indonesia. Salah satunya yaitu pada tahun 2014, pada saat peristiwa Pemilihan Umum (Pemilu) Presiden 2014. Terjadi peningkatan Indeks Harga Saham Gabungan (IHSG) LQ-45 tiga hari sebelum peristiwa. Peningkatan tersebut menjadi 859.412 dari sebelumnya 30.130. Namun terdapat beberapa fluktuasi IHSG LQ-45 tiga hari setelah 
peristiwa. Fluktuasi harga saham setelah peristiwa ini diduga karena adanya ketidakpastian politik dimana kondisi dunia politik memanas, sehingga menimbulkan situasi tidak menentu yang berakibat pada aksi profit takinginvestor di hari berikutnya (Hutami, 2014). Peristiwa politik lainnya lagi yaitu, seperti pergantian Kabinet Kerja Presiden Joko Widodo Juli 2016. Pasar merespon positif kebijakkan presiden untuk melakukan pergantian Kabinet Kerja. Perdagangan saham ditutup dengankenaikkan IHSG sebesar 49,96 poin.

Satu event tahun 2017 yang baru saja berlalu, mengenai Pemilu Kepala Daerah (Pilkada) Gubernur Daerah Khusus Ibu Kota (DKI) Jakarta juga menuai kontroversi politik yang berimbas pada iklim prediksi investor pada beberapa saham di pasar modal. Pilkada Jakarta Tahun 2017 kali ini, dilaksanakan melalui dua putaran. Putaran pertama dilaksanakan pada tanggal 15 Februari. Berdasarkan hasil rekapitulasi perhitungan suara Pilkada Putaran I, pasangan cagub-cawagung Ahok-Djarot dan Anies-Sandi berhasil sebagai pemenang sementara dengan menduduki perolehan suara teratas.

Hasil perolehan suara ini ternyata cukup menyita perhatian publik, pasalnya belakangan politik dengan menggunakan isu-isu SARA masih kuat mempengaruhi persepsi masyarakat dibandingkan hanya sekadar melihat kinerja dalam memilih calon pemimpinnya, terlebih lagi kasus berbau SARA tengah dialami sendiri oleh pasangan calon gubernur nomor urut dua yang akrab disapa Ahok. Fakta menunjukkan ternyata pasangan Ahok-Djarot mampu memperoleh suara terbanyak yakni sebesar $42,96 \%$ suara, setelah sebelumnya banyak masyarakat mengira pasangan ini akan dirugikan oleh adanya kasus tersebut. 
Ida Ayu Nirma Prameswari dan Made Gede Wirakusuma. Analisis...

Berdasarkan hasil perhitungan resmi tersebut, maka Komisi Pemulihan Umum (KPU) DKI Jakarta kemudian memutuskan pasangan cagub-cawagub AhokDjarot dan Anies-Sandi berhak melaju ke Pilkada Putaran II. Antusiame masyarakat luas khususnya masyarakat DKI Jakarta diramalkan akan lebih meningkat pada Pilkada Putaran II, mengingat kedua pasangan calon akan semakin ketat bersaing untuk memperlihatkan keunggulan masing-masing, sehingga Putaran II ini digadang-gadang akan menyeret perhatian masyarakat lebih banyak lagi.

Menurut Analis Binaartha Sekuritas yakni Bapak Reza Priyambada, dalam wawancaranya bersama Detik Finance (19/4/2017) menyatakan peristiwa politik seharusnya tidak memengaruhi pasar, tetapi kenyataannya hal tersebut berimbas pada persepsi pasar. Reza berpendapat Pilkada DKI Jakarta mempunyai potensi dalam menggerakkan saham-saham tertentu, sebab ada yang berhubungan dengan perusahaan emiten. Seperti cawagub Sandiaga yang dikenal sebagai pendiri PT. Saratoga, diyakini oleh investor jika Sandi menang akan mempengaruhi saham PT. Saratoga. Akibatnya timbul persepsi investor untuk membeli saham PT. Saratoga sehingga sahamnya naik dan akan berpengaruh pada return sahamnya. Sementara itu, jika pasangan Ahok-Djarot menang maka diprediksi saham PT. Agung Podomoro Land akan semakin kuat, karena diprediksi berhubungan dengan proyek reklamasi di Jakarta Utara, kemudian akan memberikan investor asumsi bahwa di masa mendatang akan terjadi return postif (Sugianto, 2017).

Fakta kasus dan isu peristiwa Pemilu di atas mencerminkan bahwa peristiwa politik secara tidak langsung memiliki pengaruh terhadap pasar saham, 
khususnya harga saham, yang akan berimbas pada IHSG, return yang diterima investor dan volume aktivitas perdagangan saham. Berdasarkan pemaparan teori dan kasus, peneliti mengangkat peristiwa Pemilihan Gubernur DKI Jakarta Tahun 2017 untuk dilihat reaksi pasarnya.

Rumusan masalah yang dapat diajukan yaitu apakah terdapat perbedaan rata-rata abnormal return dan trading volume activity sebelum dan sesudah Pemilihan Gubernur DKI Jakarta Tahun 2017. Penelitian ini dilakukan guna membuktikan secara empiris terdapatbedarata-rata abnormal returndan trading volume activitypada Pemilihan Gubernur DKI Jakarta Tahun 2017. Hasil penelitian ini secar teoretis diharapkan mampu menyumbangkan bukti empiris mengenai teori kandungan informasi dan efisiensi pasar dalam menjelaskan reaksi pasar pada peristiwa Pemilihan Gubernur DKI Jakarta Tahun 2017 dan secara praktis sebagai acuan investor dalammempertimbangkandan memprediksi harga saham kemudian mengambil keputusan terhadap suatu peristiwa yang terjadi.

Istilah kandungan informasi digunakan untuk isu-isu yang menguji suatu event memberikan pengaruh pada harga saham saat terjadinyevent(Watts \& Zimmerman, 1986). Foster (1986) mengemukakan bahwa kandungan informasi mempunyai artireleaseberita baru/pengumuman yang berakibat pada perubahan return. Ekspektasi pasar modal padainformasi yang terkandung, dampak suatu pengumaman/peristiwapadasebaranreturn,dan kredibilitas sumber informasi merupakan tiga faktor yang memberikan pengaruh pada isi informasi. Apabila suatu pengumuman/peristiwaberisi informasi, maka selayaknya pasar akan merespon saat terjadinya pengumuman/peristiwa. Reaksi tersebut 
Ida Ayu Nirma Prameswari dan Made Gede Wirakusuma. Analisis...

dibuktikan oleh adanya harga saham yang berubah. Adanya reaksi sebagaimana disebutkan oleh Hartono (2014) bisa diukur melalui abnormal return, seperti pada Gambar 1 berikut ini:

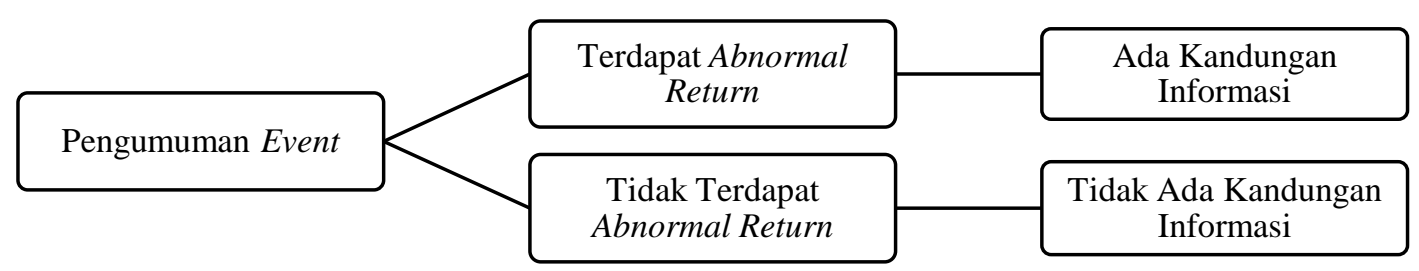

\section{Gambar 1. Desain Penelitian}

Sumber: Hartono, 2014

Uji terhadap kandungan informasi hanya digunakan untuk menguji ada atau tidaknya reaksi pasar, tidak untuk menguji kecepatan reaksi.

Salah satu penilaian yang dapat dilakukan untuk mengetahui kualitas dari pasar modal yaitu dengan melihat efisiensi pasarnya.Pasar modal efisien diartikan sebagai pasar dimana harga sahamsudahmenunjukkan informasi secara cepat dan ada kaitan (relevan) (Husnan,2001:264). Pasar efisien bila merespon dengan cepat dan akurat menggunakan informasi tersedia (Trisnadi, 2016). Efisiensi pasar modal terbagi ke dalam tiga bentuk menurut Bodie et al. (2005), diantaranya adalah: (1) Efisiensi bentuk lemah,(2) Efisiensi bentuk setengah kuat, dan (3) Efisiensi bentuk kuat.

Aktivitas investasi yang diinginkan oleh para investor bisa dilakukan melalui pasar modal salah satunya. Pasar modal ialah tempat dimana pelaku pasar bisa memperdagangkan surat-surat berharga dan bermacam instrumen keuangan dengan berbagai tingkat risiko tertentu yang akan diterima, baik itu untung maupun rugi. Perusahaan yang membutuhkan dana dan kelebihan dana 
menganggap pasar modal adalah tempat alternatif dan potensial dalam berinvestasi (Andansari, 2016).

Setiap pilihan investasi yang dilakukan oleh investor, investor akan memperoleh return yang disertai dengan suatu tingkat risiko. Oleh sebab itu, sebelum melakukan investasinya, investor perlu dan harus mengetahui informasiinformasi yang tercermin pada nilai perusahaan dan harga dari instrumen keuangan. Hal ini diperlukan agar investor dapat meraih keuntungan yang maksimal dan mampu mengurangi tingkat risiko yang akan diterima nantinya.

Pasar modal memiliki keterlibatan dan manfaat bagi kelangsungan perekonomian suatu negara dalam mengelola dan menempatkan dana. Pentingnya peranan pasar modal tersebut karena melaksanakan fungsi sebagai wadah pendanaan usaha dari masyarakat (investor)(Purwana Taunay, 2013). Menurut Martalena dan Malinda (2011), peranan pasar modal yaitu: sebagai alternatif investasi, sebagai tempat untuk mengalokasikan dana secara efisien, memberikan kemungkinan untuk investor mempunyai perusahaan berprospek dan sehat, memungkinkanmengelola perusahaan dengan transparan dan profesional, serta sebagai sarana untuk meningkatkan aktivitas ekonomi nasional.

Investor yang melakukan investasi di pasar modal tentu akan mengharapkan adanya return atas investasinya. Return ialah tingkat keuntungan nyata yang diperoleh pelaku pasar modal atau pemegang saham pada investasi sahamnya.Reaksi pasar terhadap adanya informasi baru yang diterima dapat diukur dengan melihat abnormal return.Abnormal returnadalah selisih actual return dengan expected return(Samsul, 2006:275).Abnormal return saham 
Ida Ayu Nirma Prameswari dan Made Gede Wirakusuma. Analisis...

dihitung sebagai selisih return sesungguhnya saham individua dengan return pasarnya (Tobing, 2012). Abnormal returnbernilai positif pada saat tingkat return sesungguhnyatidak lebih kecil dari tingkat return ekspektasi. Sebaliknya, abnormalreturn negatif apabila tingkat return realisasian tidak lebih besar dari return ekspektasiannya.Brown\& Warner (1985), mengatakan dalam mengestimasi return ekspektasi dapat digunakanmean adjusted model,market adjusted model,dan market model sebagai model estimasi.

Aktivitas volume perdagangan saham ialah suatu instrumen yang bisa dipakai untuk membuktikan ada reaksi pasar pada informasi dengan tolok ukur perubahan aktivitas volume perdagangan saham di pasar (Widi Hartawan, dkk., 2015). Volume aktivitas perdagangan bisa disebabkan karena investor melakukan suatu permintaan dan penawaran terhadap saham di bursa. Bila volume permintaan dan penawaran meningkat terhadap saham, maka akan memberikan pengaruh yang besar terhadap naik-turunnya (fluktuasi) volume perdagangan di bursa pasar modal. Terjadinya hal ini menunjukkan semakin tingginya volume dan frekuensi saham yang diperdagangkan, pun menunjukkan investor tertarik pada saham-saham tersebut. Return bernilai tinggi dihasilkan dari saham yang volume perdagangannya tinggi (Chordia \&Bhaskaran, 2000).

Studi peristiwa adalah teknik yang paling umum digunakan untuk memeriksa dampak berbagai kejadian pada efisiensi pasar saham.Metode ini digunakan oleh Ismail dan Suhardjo(2001), Bailey et al. (2005) dan Beaulieu et al. (2006) untuk mempelajari peristiwa politik.Selain itu, Henderson (1990) juga mendukung metodologi event studytersebut dan memberikan hasil yang lebih baik 
saat mengukur reaksi pasar baik secara keseluruhan atau pada perusahaan perorangan. Aplikasi terhadap metode event studykini telah mengalami suatu perkembangan yang telah menyentuh aspek makro ekonomi hingga isu lingkungan dan politik (Diman Arde, 2017).

Penelitian-penelitianterhadap peristiwa politik yang terjadi di dalamdan luar negeri banyak dilakukan. Penelitian tersebut guna melihat apakah ada kandungan informasidari peristiwa politik yang menyebabkan terjadinya reaksi pasar.Chiu et al. (2005) membuktikan bahwa pemilihan politik di Korea Selatan mempengaruhi perilaku investor asing di pasar modal.Frey dan Waldenstrom (2004), Bailey et al. (2005), Beaulieu et al. (2006), dan Aktas dan Oncu (2006)mengemukakan bahwa peristiwa politik berpengaruh kuat terhadap tingkat pengembalian dan volume perdagangan.

Penelitian Pamungkas, dkk. (2015) menunjukkan ada beda rata-rata abnormal return dan trading volume activity sebelum dan sesudah peristiwa Pemilu 2014. Sedangkan, penelitian Chandra, dkk.(2014) memberikan hasil tidak ada beda rata-rata abnormal return dan rata-rata trading volume activitysebelumsesudah Pemilu 2004 \& 2009.Penelitian sejenis padaPilkada DKI Jakarta 2012, memperlihatkan rata-rata abnormal returndan trading activitytida ada beda. Bhakti Pratama, dkk. (2015) dan Sureni Yuniarthi (2016) meneliti reaksi pasar modal terhadap peristiwa pencalonan Jokowi dan Pelantikkannya menjadi kepla negara RI menunjukan tidak terdapat reaksi pasar yang berbeda. Penelitian Bialkowski et al. (2006 menghasilkan abnormal return dan trading volume 
Ida Ayu Nirma Prameswari dan Made Gede Wirakusuma. Analisis...

activity perbedaanya tidak ada padaPemilu.Penelitian mengenai Pilpres Amerika Serikat 2016 memberikan hasil bahwa tidak ada perbedaan (Permata Sari, 2017).

Kerangka konseptual dalam penelitian ini ditampilkan pada Gambar 2.

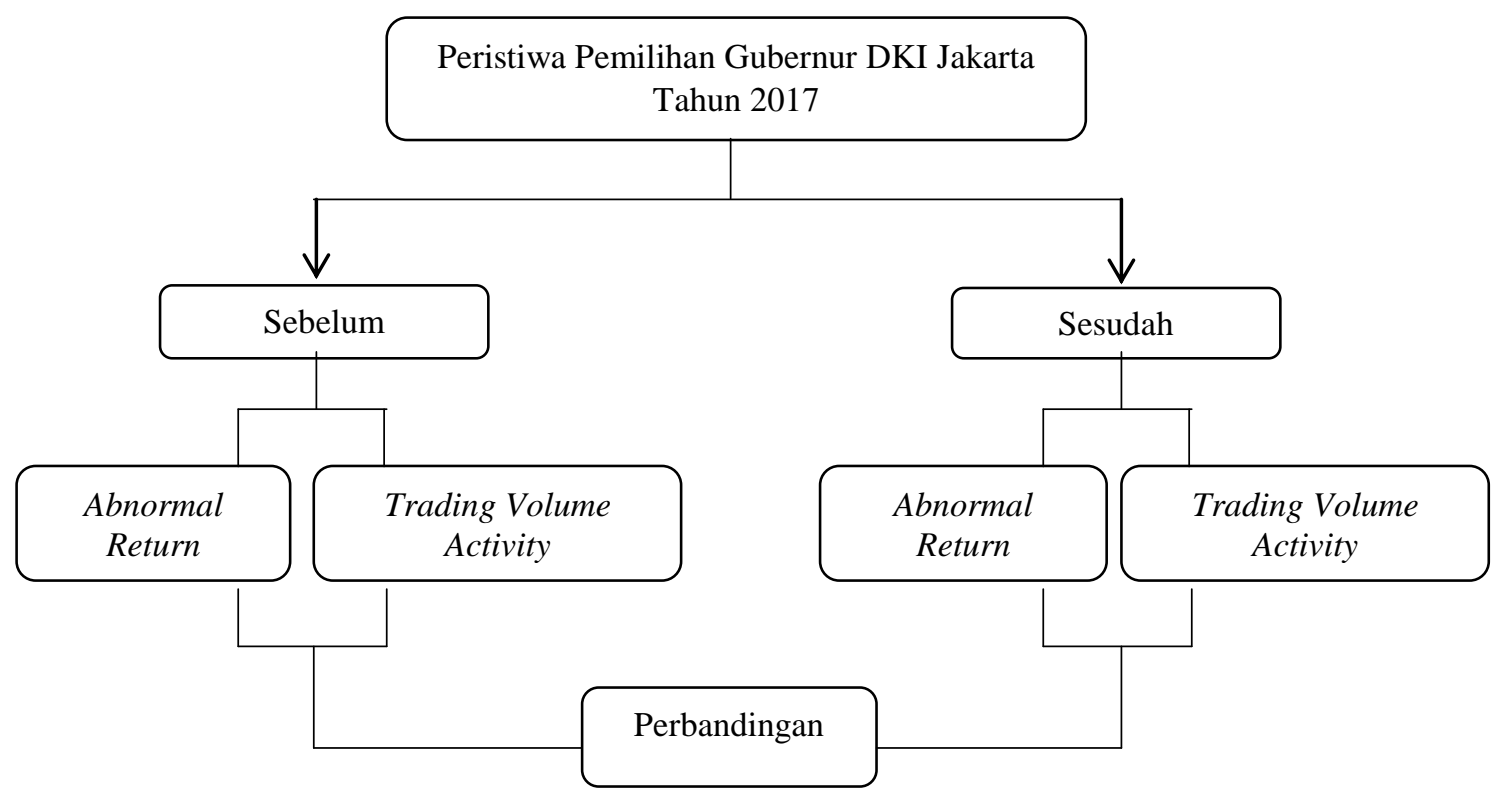

Gambar 2. Kerangka Konseptual Penelitian

Sumber: Data diolah, 2017

Pemilihan Gubernur DKI Jakarta sebagai sebuah eventdiduga mempunyai kandungan informasi yang berpengaruh pada reaksi pasar. Penelitian Permana (2013) pada Pilkada DKI Jakarta 2012 menunjukkan terdapat perbedaan abnormal return positif. Hasil yang sama juga ditunjukkan oleh penelitian Wardhani (2012) Berdasarkan paparan di atas, dapat diajukan hipotesis pertama:

$\mathrm{H}_{1}$ : Terdapat perbedaan rata-rata abnormal return sebelum dan sesudah Pemilihan Gubernur DKI Jakarta Tahun 2017.

Reaksi pasar juga dibuktikan oleh adanya perubahan aktivitas perdagangan yang nampak pada volume perdagangan saham. Penelitian Budiman (2015) dan Harjanto (2008) menunjukkan ada perbedaan signifikantrading volume 
activitypada peristiwa politik. Berdasarkan paparan di atas, dapat diajukan hipotesis kedua penelitian ini:

$\mathrm{H}_{2}$ : Terdapat perbedaan rata-rata trading volume activity sebelum dan sesudah Pemilihan Gubernur DKI Jakarta Tahun 2017.

\section{METODE PENELITIAN}

Pendekatan berbentuk kuantitatif komparatifditerapkan dalam penelitian ini.Event yang diteliti adalah peristiwa Pemilihan Gubernur DKI Putaran II Tahun 2017 yang dilaksanakan tanggal 19 April 2017. Penelitian ini menggunakan periode waktu singkat selama 11 hari kerja Bursa Efek Indonesia (BEI) dengan pembagian: hari sebelum ( $\mathrm{t}-1$ sampai $\mathrm{t}-5)$, event date $(\mathrm{t}=0)$, dan hari setelah $(\mathrm{t}+1$ sampai t+5). Periode waktu singkat 11 hari digunakan dengan asumsi bahwa memadai dan cukup bagi pelaku pasar dalam merespon peristiwa politik ini.Sebuah event window period yang terlalu panjang akan menyerap dampak peristiwa eknomi, non ekonomi dan politik lainnya yang tidak termasuk dalam penelitian, sedangkan jendela yang terlalu pendek juga tidak dapat menganalisis efek dari suatu peristiwa dengan baik (Nazir et al., 2014)

Penelitian ini memiliki ruang lingkup dan berlokasi di BEI dengan mengakses data sekunder meliputi harga dan jumlah saham beredar, serta jumlah saham diperdagangkan pada seluruh perusahaan LQ-45 periode Februari-Juli 2017 melalui situs website. Variabel penelitian ini adalah berupa abnormal return dan trading volume activity. 
Ida Ayu Nirma Prameswari dan Made Gede Wirakusuma. Analisis...

Perhitungan expected return memakai market adjusted model, karena memberikan kemudahan dalam melakukan deteksi terhadap abnormal return. Tahapan menghitung abnormal return:

1). Mencariactual return, dengan rumus:

$$
R_{i, t}=\frac{P_{i, t}-P_{i, t-1}}{P_{i, t-1}}
$$

Keterangan:

$R_{i, t}=$ Return sesungguhnya yang terjadi untuk sekuritas ke-ipada periodeperistiwa ke-t.

$P_{i, t}=$ Harga sekarang relatif.

$P_{i, t-1}=$ Harga sebelumnya.

2). Mencarireturn pasar harian, dengan rumus:

$$
\mathrm{R}_{m t}=\frac{I H S G_{t}-I H S G_{t-1}}{I H S G_{t-1}}
$$

Keterangan:

$\mathrm{R}_{\mathrm{mt}} \quad=$ Return pasar pada waktu ke-t.

$\mathrm{IHSG}_{\mathrm{t}}=$ Indeks Harga Saham Gabungan hari ke-t

$\mathrm{IHSG}_{\mathrm{t}-1} \quad=$ Indeks Harga Saham Gabungan hari ke- ${ }_{\mathrm{t}-1}$

3). Mencariexpected return, dengan rumus:

$$
\mathrm{E}\left(\mathrm{R}_{i, t}\right)=\mathrm{R}_{m t}
$$

Keterangan:

$$
\begin{aligned}
\mathrm{E}\left(\mathrm{R}_{i, t}\right) & =\text { Expected return } \\
\mathrm{R}_{m t} & =\text { Return pasar harian }
\end{aligned}
$$

4). Mencariabnormal returnsetiap perusahaan, dengan rumus:

$$
\mathrm{AR}_{\mathrm{i}, \mathrm{t}}=\mathrm{R}_{\mathrm{i}, \mathrm{t}}-\mathrm{E}(\mathrm{Ri}, \mathrm{t}) .
$$

Keterangan:

$\mathrm{AR}_{\mathrm{i}, \mathrm{t}}=$ =Abnormal returnsekuritas i pada periode peristiwa ke- $\mathrm{t}$

$\mathrm{R}_{\mathrm{i}, \mathrm{t}} \quad=$ Actual returnsekuritas i pada periode perisiwa ke- $\mathrm{t}$

$\mathrm{E}\left(\mathrm{Ri}_{\mathrm{i}, \mathrm{t}}\right) \quad=$ Expected Return 
5). Mencari rata-rata abnormal return, dengan rumus:

$$
\mathrm{AAR}=\frac{\sum_{i=1}^{n}-A R_{i t}}{n}
$$

Keterangan:

$\mathrm{AAR}=$ Rata-rata abnormal return

$\mathrm{AR}_{i, t}=$ Abnormal returnsekuritas ke-i pada periode- $\mathrm{t}$

$\mathrm{n}=$ Jumlah sampel

Tahapan mencari rata-rata trading volume activityyaitu:

1) Mencari trading volume activity setiap saham selama pengamatan, dengan rumus:

$$
\begin{aligned}
& \text { Ssaham } i \\
& \mathrm{TVA}=\frac{\text { ditransaksikan waktu } t}{\sum \text { saham } i}
\end{aligned}
$$

2) Mencari rata-rata trading volume activity semua saham perusahaan sampel, dengan rumus:

$$
\mathrm{ATVA}=\frac{\sum_{i=1}^{n} T V A i, t}{n}
$$

Keterangan :

ATVA = Rata-rata trading volume activity

TVA $_{i, \mathrm{t}}=$ Trading volume activity sekuritas $i$ pada periode $\mathrm{t}$

$\mathrm{n}$

= Jumlah sampel

Data kuantitatif dan kualitatif digunakan dalam penelitian ini. Data kuantitatif berupa jumlah seluruh perusahaan, IHSG, harga saham harian, dan volume perdagangan saham harian.Data kualitatif berupa daftar nama perusahaan dalam LQ-45 Periode Februari-Juli 2017. Data sekunder dalam penelitian ini diperoleh melalui tinjauan kepustakaan. 
Ida Ayu Nirma Prameswari dan Made Gede Wirakusuma. Analisis...

Perusahaan yang tergabung dalam LQ-45 periode Februari-Juli 2017 di BEI merupakan populasi penelitian ini. Teknik purposive sampling digunakan dalam penentuan sampel dengan kriteria perusahaan yang tergabung dalam Indeks LQ-45 Periode Februari-Juli 2017yang tidak melakukan coorporate actions(pembagian deviden, stock spilt, dan right issue). Pemilihan Indeks LQ-45 sebagai sampel yaitu dengan harapan dapat merepresentasikan seluruh perusahaan dari berbagai sektor yang terdaftar di BEI yang saham-sahamnya aktif diperdagangkan.

Metode observasi non partisipan diterapkan dalam pengumpulan data. Semua data berkaitan yang dikumpulkan akan dianalisis bertahap mulai dari statistik deskriptif, uji normalitas, baru kemudian uji paired samples t-testuntuk pengujian hipotesis.Pengujian statistik ujipaired samples t-testdilaksanakanuntuk mengetahui tingkat signifikansi perbedaan rata-rata abnormal return dan volume trading activity sebelum dan sesudah Pemilihan Gubernur DKI Jakarta Tahun 2017. Kriteria uji paired sample t-test ini adalah apabila nilai $\operatorname{Sig}<0,05, \mathrm{H}_{1}$ diterima, sebaliknya apabila Sig $>0,05$ maka $H_{1}$ ditolak (Ghozali, 2016).Untuk data berdistribusi tidak normal akan dilakukan pengujian wilcoxon signed rank test.

\section{HASIL DAN PEMBAHASAN}

Berdasarkan kriteria diperoleh sampel sebanyak 42 perusahaan. Jumlah perusahaan yang dijadikan sampel tersaji dalam Tabel 1. 
ISSN: 2302-8556

E-Jurnal Akuntansi Universitas Udayana Vol.22.2. Februari (2018): 944-975

Tabel 1.

Jumlah Sampel Perusahaan

\begin{tabular}{|c|c|c|}
\hline No & Keterangan & Jumlah Perusahaan \\
\hline 1 & $\begin{array}{l}\text { Perusahaan terdaftar dalam Indeks LQ-45 Periode Februari- } \\
\text { Juli } 2017\end{array}$ & 45 \\
\hline 2 & $\begin{array}{l}\text { Perusahaan LQ-45 Periode } \quad \text { Februari-Juli } 2017 \text { yang } \\
\text { melakukan corporate action: } \\
\quad-\quad \text { Pembagian deviden } \\
-\quad \text { Stock split } \\
-\quad \text { Right Issue }\end{array}$ & $\begin{array}{l}3 \\
0 \\
0\end{array}$ \\
\hline & Total sampel penelitian & 42 \\
\hline
\end{tabular}

Sumber: Bursa Efek Indonesia, 2017

Perhitungan rata-rata abnormal return dilakukan melalui beberapa tahap yakni dengan menghitung actual return, return pasar harian, expected return, dan abnormal return masing-masing sekuritas selama periode pengamatan peristiwa.

Tabel 2.

Jumlah Sebaran Perhitungan Actual Return

\begin{tabular}{ccccc}
\hline Periode & Postif & Nol & Negatif & Total \\
\hline $\mathrm{t}-5$ & 13 & 4 & 25 & 42 \\
\hline $\mathrm{t}-4$ & 23 & 9 & 10 & 42 \\
\hline $\mathrm{t}-3$ & 10 & 7 & 25 & 42 \\
\hline $\mathrm{t}-2$ & 5 & 7 & 30 & 42 \\
\hline $\mathrm{t}-1$ & 26 & 3 & 13 & 42 \\
\hline $\mathrm{t}=0$ & 0 & 42 & 0 & 42 \\
\hline $\mathrm{t}+1$ & 9 & 4 & 29 & 42 \\
\hline $\mathrm{t}+2$ & 26 & 4 & 12 & 42 \\
\hline $\mathrm{t}+3$ & 24 & 5 & 13 & 42 \\
\hline $\mathrm{t}+4$ & 23 & 9 & 10 & 42 \\
\hline $\mathrm{t}+5$ & 15 & 5 & 22 & 42 \\
\hline \multirow{2}{*}{ Total } & 174 & 99 & 189 & 462 \\
& $(37,66 \%)$ & $(21,43 \%)$ & $(40,91 \%)$ & $(100 \%)$ \\
\hline
\end{tabular}

Sumber: Data sekunder diolah, 2017

Tabel 2 memperlihatkan actual return yang paling banyak terjadi di sekitar periode peristiwa adalah actual return bernilai negatif, yaitu sebanyak 189 actual return atau sebanyak 40,91\%. Pada Tabel 3 dan disajikan hasil perhitungan ratarata actual return. 
Tabel 3.

Hasil Perhitungan Rata-rata Actual Return secara Harian

\begin{tabular}{ccc}
\hline Tanggal & Periode & Rata-rata Actual Return \\
\hline 11 April 2017 & $\mathrm{t}-5$ & 0,0004 \\
12 April 2017 & $\mathrm{t}-4$ & 0,0131 \\
13 April 2017 & $\mathrm{t}-3$ & $-0,0057$ \\
17 April 2017 & $\mathrm{t}-2$ & $-0,0087$ \\
18 April 2017 & $\mathrm{t}-1$ & 0,0079 \\
19 April 2017 & $\mathrm{t}=0$ & 0,0000 \\
20 April 2017 & $\mathrm{t}+1$ & $-0,0084$ \\
21 April 2017 & $\mathrm{t}+2$ & 0,0086 \\
25 April 2017 & $\mathrm{t}+3$ & 0,0069 \\
26 April 2017 & $\mathrm{t}+4$ & 0,0071 \\
27 April 2017 & $\mathrm{t}+5$ & 0,0036 \\
\hline
\end{tabular}

Sumber: Data sekunder diolah, 2017

Rata-rata actual return yang terjadi di sekitar peristiwa hampir seluruhnya bernilai positif, hanya 2 hari pada sebelum peristiwa (t-2 dan t-3) dan sehari setelah peristiwa bernilai negatif. Hal ini mencerminkan penurunan harga saham lebih banyak terjadi pada hari-hari sebelum peristiwa.

Setelah memperoleh actual return, perhitungan selanjutnya dilakukan untuk mendapatkan expected return. Berikut merupakan hasil perhitungan dan pergerakkan expected return yang tersaji pada Tabel 4.

Tabel 4.

Hasil Perhitungan Expected Return secara Harian Selama Periode Peristiwa

\begin{tabular}{ccc}
\hline Tanggal & Periode & Expected Return \\
\hline 11 April 2017 & $\mathrm{t}-5$ & $-0,0029$ \\
12 April 2017 & $\mathrm{t}-4$ & 0,0029 \\
13 April 2017 & $\mathrm{t}-3$ & $-0,0049$ \\
17 April 2017 & $\mathrm{t}-2$ & $-0,0070$ \\
18 April 2017 & $\mathrm{t}-1$ & 0,0052 \\
19 April 2017 & $\mathrm{t}=0$ & - \\
20 April 2017 & $\mathrm{t}+1$ & $-0,0020$ \\
21 April 2017 & $\mathrm{t}+2$ & 0,0124 \\
25 April 2017 & $\mathrm{t}+3$ & 0,0029 \\
26 April 2017 & $\mathrm{t}+4$ & 0,0081 \\
27 April 2017 & $\mathrm{t}+5$ & $-0,0034$ \\
\hline
\end{tabular}

Sumber: Data sekunder diolah, 2017 
Expected return selama periode peristiwa mengalami fluktuasi. Awalnya, pada t5expected return bernilai negatif, disusul peningkatan pada sehari setelahnya ( $\mathrm{t}-4)$ namun kembali mengalami penurunan pada dua dan tiga hari sebelum peristiwa. Sehari sebelum dan sehari setelah peristiwa expected return bernilai positif dan negatif. Selanjutnya pada hari kedua sampai hari keempat sesudah peristiwa, expected return terus bernilai positif, kemudian kembali mengalami penurunan pada hari kelima setelah peristiwa. Tabel 5 menampilkan hasil perhitungan abnormal return setelah diperoleh actual return dan expected return.

Tabel 5.

Hasil PerhitunganRata-rata Abnormal Return di Sekitar Peristiwa

\begin{tabular}{ccc}
\hline Tanggal & Periode & $\begin{array}{c}\text { Rata-Rata Abnormal } \\
\text { Return }\end{array}$ \\
\hline 11 April 2017 & $\mathrm{t}-5$ & 0,0030 \\
12 April 2017 & $\mathrm{t}-4$ & 0,0104 \\
13 April 2017 & $\mathrm{t}-3$ & $-0,0018$ \\
17 April 2017 & $\mathrm{t}-2$ & $-0,0025$ \\
18 April 2017 & $\mathrm{t}-1$ & 0,0034 \\
19 April 2017 & $\mathrm{t}=0$ & - \\
20 April 2017 & $\mathrm{t}+1$ & $-0,0061$ \\
21 April 2017 & $\mathrm{t}+2$ & $-0,0019$ \\
25 April 2017 & $\mathrm{t}+3$ & 0,0048 \\
26 April 2017 & $\mathrm{t}+4$ & 0,0000 \\
27 April 2017 & $\mathrm{t}+5$ & 0,0065 \\
\hline
\end{tabular}

Sumber: Data sekunder diolah, 2017

Merujuk Tabel 5, abnormal return bernilai negatif terjadi pada hari -2, -3, +1 , dan +2 . Sedangkan abnormal return bernilai positif terjadi pada periode hari $1,-4,-5,+3,+4$, dan +5 . Pada periode pengamatan sebelum peristiwa Pilkada DKI Jakarta Tahun 2017, abnormal return mengalami fluktuasi hampir di setiap harinya. Reaksi mengalami peningkatan pada hari -1 , dan menurun pada hari -2 , kemudian meningkat lagi pada hari -3 dan meningkat drastis pada hari -4 , serta kembali menurun pada hari -5 . Reaksi abnormal return setelah peristiwa 
Ida Ayu Nirma Prameswari dan Made Gede Wirakusuma. Analisis...

mengalami penurunan pada hari +1 , namun mengalami peningkatan kembali pada hari $+2,+3$ dan +5 , sebelum sempat menurun pada hari +4 . Reaksi abnormal return tertinggi terjadi pada empat hari sebelum Pilkada DKI Jakarta Tahun 2017 dilangsungkan, dan reaksi abnormal return terendah terjadi pada waktu sehari setelah Pilkada DKI Jakarta Tahun 2017 dilangsungkan.

Tabel 6.

Hasil Analisis Statistik DeskriptifRata-rata Abnormal Return

\begin{tabular}{lccc}
\hline & & $\begin{array}{c}\text { Rata-rata Abnormal } \\
\text { Return sebelum }\end{array}$ & $\begin{array}{c}\text { Rata-rata Abnormal } \\
\text { Return sesudah }\end{array}$ \\
\hline $\mathrm{N}$ & Valid & 42 & 42 \\
Mean & Missing & 0 & 0 \\
Std. Deviation & & 0,0025 & 0,0007 \\
Minimum & 0,0081 & 0,0074 \\
Maximum & $-0,0161$ & $-0,0132$ \\
\hline
\end{tabular}

Sumber: Data diolah, 2017

Tabel 6 menjelaskan bahwa, untuk rata-rata abnormal return sebelum terjadi Pemilihan Gubernur DKI Jakarta 2017 meliliki nilai terendah 0,0161(Media Citra Nusantara Tbk) dan nilai tertinggi 0,0221(PP (Persero) Tbk) dengan nilai mean sebesar 0,0025. Nilai standar deviasi sebesar 0,0081.Sedangkan rata-rata abnormal return sesudah Pemilihan Gubernur DKI Jakarta 2017, memiliki nilai terendah -0,0132(PP (Persero) Tbk) dan nilai tertinggi 0,0165 (Matahari Department Store Tbk). Nilai mean 0,0007. Nilai standar deviasi sesudah yaitu sebesar 0,0074 . 
Tabel 7.

Hasil Uji NormalitasRata-rata Abnormal Return

\begin{tabular}{llcc}
\hline & & $\begin{array}{c}\text { AAR } \\
\text { Sebelum }\end{array}$ & $\begin{array}{c}\text { AAR } \\
\text { Sesudah }\end{array}$ \\
\hline \multirow{2}{*}{ Normal Parameters(a,b) } & & & \\
& Mean & 42 & 42 \\
Most Extreme & Std. Deviation & 0,003 & 0,001 \\
Differences & Absolute & 0,008 & 0,007 \\
& Positive & 0,146 & 0,103 \\
Kolmogorov-Smirnov Z & Negative & 0,146 & 0,095 \\
Asymp. Sig. (2-tailed) & & $-0,097$ & $-0,103$ \\
\end{tabular}

Sumber: Data diolah, 2017

Merujuk Tabel 7, rata-rata abnormal return sebelum peristiwa memiliki nilai asymp. Sig. (2-tailed) 0,334 > 0,05 dan rata-rata abnormal return sesudah peristiwa memiliki nilai asymp. Sig. (2-tailed) 0,768>0,05. Sehingga kesimpulannya data rata-rata abnormal return sebelum dan sesudah Pemilihan Gubernur DKI Jakarta 2017 telah berdistribusi dengan normal.

Tabel 8.

Hasil Uji BedaRata-rata Abnormal Return Sebelum dan Sesudah Peristiwa

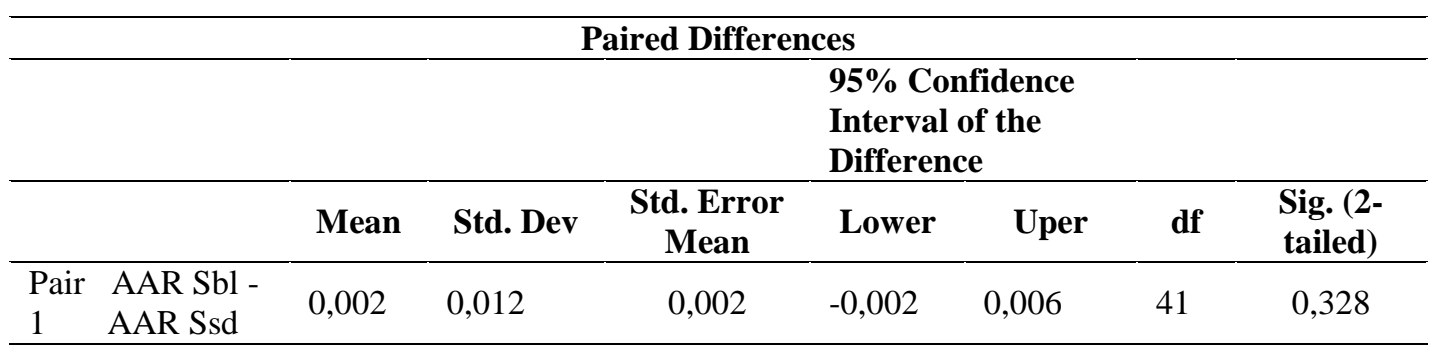

Sumber: Data diolah, 2017

Merujuk Tabel 8, nilai Sig. 0,328 >0,05. Ini berarti bahwa $\mathrm{H}_{1}$ ditolak sehingga tidak terdapat perbedaan rata-rata abnormal return sebelum dan sesudah Pemilihan Gubernur DKI Jakarta Tahun 2017. Berdasarkan hasil tersebut dapat dikatakan bahwa bagi pelaku pasar peristiwa Pemilihan Gubernur DKI Jakarta 
Ida Ayu Nirma Prameswari dan Made Gede Wirakusuma. Analisis...

Tahun 2017 tidak mempunyai imbas yang besar terhadap kegiatan pasar modal. Kandungan dalam peristiwa politik Pilkada DKI Jakarta Tahun 2017 tersebut tidak cukup untuk menggerakkan investor dalam membuat keputusan investasinya.Investor dalam melakukan pertimbangan investasi semata-mata hanya melihat peristiwa yang sedang terjadi, tetapi juga menggunakan teknik analisis fundamental maupun analisis teknikal, untuk memperoleh return maksimal dan terhindar dari risiko kerugian investasi.

Pasar hanya akan bereaksi pada peristiwa politik Pilkada DKI Jakarta, apabila peristiwa tersebut dianggap sebagai pengumuman yang memiliki kandungan informasi sehingga berdampak pada kepercayaan investor, baik kepercayaan mengenai kestabilan ekonomi, keyakinan masa depan, ataupun kepercayaan terhadap sosok calon pemimpin yang dianggap mampu mengampu kebijakan yang menstabilkan kondisi perekonomian. Para pelaku pasar cukup tenang dalam menghadapi situasi politik yang terjadi dan tercermin dalam nilai abnormal return yang tidak mengalami perbedaan secara signifikan.Hasil penelitian sejalan dengan Permata Sari(2017), Santoso dan Sri Artini (2015), dan Melati, dkk. (2014), bahwasannya peristiwa politik khususnya pemilihan umum tidak memiliki kandungan informasi yang berdampak pada kepercayaan investor dalam berinvestasi sehingga tidak menunjukkan pasar bereaksi.

Adanya perkembangan teknologi seperti dalam genggaman, membuat para investor tidaklah sulit untuk mendapatkan informasi sebagai penunjang pertimbangan dalam membuat keputusan investasi. Keterbukaan media informasi publik baik media cetak ataupun media online dianggap mampu memberikan 
informasi secara cepat dan update.Informasi mengenai survei yang dilakukan oleh lembaga-lembaga survei terkemuka dan terpercaya di Indonesia terhadap hasil Pilkada DKI Jakarta Tahun 2017, menyebabkan bahwa pada dasarnya sejak dini investor telah bisa memprediksi hasil dari Pilkada DKI tersebut. Oleh sebab itu, investor sudah bisa menetapkan langkah investasi apa yang akan diambil (preventif) dalam menghadapi peristiwa politik Pemilihan Gubernur DKI Jakarta Tahun 2017.

Perhitungan rata-rata trading volume activity diperoleh melalui data-data jumlah saham ditransaksikan dan jumlah saham beredar untuk sampel perusahan selamapengamatan peristiwa Pemilihan Gubernur DKI Jakarta 2017. Tabel 9 berikut menampilkan hasil perhitungan rata-rata trading volume activity.

\section{Tabel 9.}

Hasil PerhitunganRata-rata Trading Volume Activity di Sekitar Peristiwa

\begin{tabular}{ccc}
\hline Tanggal & Periode & $\begin{array}{c}\text { Rata-Rata Trading } \\
\text { Volume Activity }\end{array}$ \\
\hline 11 April 2017 & $\mathrm{t}-5$ & 0,00330 \\
12 April 2017 & $\mathrm{t}-4$ & 0,00322 \\
13 April 2017 & $\mathrm{t}-3$ & 0,00237 \\
17 April 2017 & $\mathrm{t}-2$ & 0,00196 \\
18 April 2017 & $\mathrm{t}-1$ & 0,00292 \\
19 April 2017 & $\mathrm{t}=0$ & - \\
20 April 2017 & $\mathrm{t}+1$ & 0,00316 \\
21 April 2017 & $\mathrm{t}+2$ & 0,00219 \\
25 April 2017 & $\mathrm{t}+3$ & 0,00234 \\
26 April 2017 & $\mathrm{t}+4$ & 0,00269 \\
27 April 2017 & $\mathrm{t}+5$ & 0,00290 \\
\hline
\end{tabular}

Sumber: data sekunder diolah, 2017

Merujuk hasil perhitungan Tabel 9, terlihat pergerakan rata-rata TVA cukup fluktuatif selama pengamatan peristiwa. Pada periode sebelum peristiwa, pergerakan rata-rata TVA cenderung terus menurun, hal ini dibuktikan dari nilai rata-rata TVA t-4 yang menurun terus sampai t-2 dan mencapai nilai terendah 
Ida Ayu Nirma Prameswari dan Made Gede Wirakusuma. Analisis...

yaitu sebesar 0,00196. Namun, pada periode sehari sebelum peristiwa, nilai ratarata TVA sejenak meningkat kembali. Selanjutnya, sehari setelah peristiwa, TVA masih mengalami peningkatan hingga selama periode setelah peristiwa cenderung terus mengalami peningkatan, sebelum sempat menurun pada $t+2$ atau 2 hari setelah peristiwa dengan nilai 0,00219 .

Tabel 10.

Hasil Analisis Statistik DeskriptifRata-rata TVA

\begin{tabular}{llcc}
\hline & $\begin{array}{c}\text { Rata-rata } \\
\text { TVA } \\
\text { Sebelum }\end{array}$ & $\begin{array}{c}\text { Rata-rata } \\
\text { TVA Sesudah }\end{array}$ \\
\hline $\mathrm{N}$ & Valid & 42 & 42 \\
Mean & Missing & 0 & 0 \\
Std. Deviation & & 0,0016 & 0,0015 \\
Minimum & & 0,0015 & 0,0012 \\
Maximum & & 0,0001 & 0,0002 \\
\hline
\end{tabular}

Sumber: Data diolah, 2017

Tabel 10 menjelaskan bahwa, untuk rata-rata TVA sebelum terjadi Pemilihan Gubernur DKI Jakarta 2017 meliliki nilai terendah 0,0001 (H.M. Sampoerna Tbk dan Unilever Indonesia Tbk) dan nilai tertinggi 0,0069 (Sri Rejeki Isman Tbk). Nilai mean sebelum yaitu 0,0016 serta nilai simpangan baku sebesar 0,015. Sedangkan untuk rata-rata TVA sesudah Pemilihan Gubernur DKI Jakarta 2017, memiliki nilai terendah 0,0002(H.M. Sampoerna Tbk)dan nilai tertinggi 0,0055(Lippo Karawaci Tbk). Nilai mean sesudah yaitu 0,0015 dengan standar deviasi0,0012. 
Tabel 11.

Hasil Uji NormalitasRata-rata TVA

\begin{tabular}{llcc}
\hline & & $\begin{array}{c}\text { ATVA } \\
\text { Sebelum }\end{array}$ & $\begin{array}{c}\text { ATVA } \\
\text { Sesudah }\end{array}$ \\
\hline $\mathrm{N}$ & & 42 & 42 \\
Normal Parameters(a,b) & Mean & 0,002 & 0,002 \\
& Std. Deviation & 0,002 & 0,001 \\
Most Extreme & Absolute & 0,207 & 0,167 \\
Differences & Positive & 0,207 & 0,167 \\
& Negative & $-0,170$ & $-0,130$ \\
Kolmogorov-Smirnov Z & & 1,341 & 1,085 \\
Asymp. Sig. (2-tailed) & & 0,055 & 0,189 \\
\hline
\end{tabular}

Sumber: Data diolah, 2017

Tabel 11 menunjukkan rata-rata TVA sebelum peristiwa nilai asymp. Sig. (2tailed) 0,055 > 0,05 dan rata-rata TVA sesudah peristiwa memiliki nilai asymp. Sig. (2-tailed) 0,189 >0,05. Sehingga disimpulkan data rata-rata TVA sebelum dan sesudah Pemilihan Gubernur DKI Jakarta 2017 telah berdistribusi dengan normal.

Tabel 12.

Hasil Uji BedaRata-rata TVA Sebelum dan Sesudah Peristiwa

\begin{tabular}{cccccccc}
\hline \multicolumn{7}{c}{ Paired Differences } \\
\hline \multicolumn{7}{c}{$\begin{array}{c}\text { 95\% Confidence } \\
\text { Interval of the } \\
\text { Difference }\end{array}$} \\
\hline $\begin{array}{c}\text { MTVA Sbl } \\
\text { ATVA Ssd }\end{array}$ & 0,0000762 & 0,0008275 & 0,0001277 & $-0,0001817$ & 0,0003341 & 41 & 0,554 \\
\hline
\end{tabular}

Sumber: Data diolah, 2017

Berdasarkan Tabel 12, hasil perhitungan Sig. 0,554 > 0,05. Ini berarti bahwa $\mathrm{H}_{2}$ ditolak sehingga tidak terdapat perbedaan rata-rata trading volume activity sebelum dan sesudah Pemilihan Gubernur DKI Jakarta Tahun 2017.

Tidak terdapatnya perbedaan ini mencerminkan bahwa informasi yang terkandung dalam peristiwa Pilkada DKI Jakarta Tahun 2017 ini tidak sampai 
Ida Ayu Nirma Prameswari dan Made Gede Wirakusuma. Analisis...

menimbulkan perdagangan saham di atas atau di bawah normal. Hasil penelitian ini sama denga Saputra (2016), Purba dan Handayani (2017), dan Simanjuntak (2017).Namun, penelitian ini berbeda dengan Budiman (2015) dan Latifah (2017). Hal ini mengindikasikan bahwa tidak semua peristiwa politik akan menimbulkan reaksi dari pelaku pasar modal. Rekasi pasar modal pada peristiwa politik yang diukur dari rata-rata trading volume activity berbeda-beda tergantunng dari jenis saham yang diteliti dan karakteristik perilaku investor dalam menyikapinya. Apabila suatu peristiwa dianggap memiliki kandungan informasi positif, yang direspon sebagai kabar baik dan memiliki potensi dalam memberikan keuntungan, maka investor cenderung lebih cepat membeli saham dan tercermin pada aktivitas volume perdagangan. Sebaliknya, apabila pelaku pasar menganggap peristiwa mempunyai kandungan informasi negatif sehingga memiliki potensi yang menyebabkan kerugian,maka investor cenderung menjual saham lebih agar tidak semakin merugi dan investasi yang dilakukan tetap aman.

Pasar yang tidak bereaksi mencerminkaninvestorsudah bisa mengantisipasi peristiwa politik ini sehingga tidak tergesa-gesa dalam menjual ataupun membeli saham di sekitar peristiwa berlangsung.Sikap antisipasi investor ini ditunjang oleh adanya informasi publik yang bisa diakses luas oleh para investor dan menyebabkan informasi yang beredar sudah merata bagi pelaku pasar, sehingga aktivitas perdagangan di pasar modal nampak normal dan tidak menunjukkan perbedaan yang signifikan di sekitar periode pengamatan.

Implikasi penelitian ini secara teoretis dapat memberikan bukti empiris yang menguatkan teori kandungan informasi dan secara praktis dapat menjadi 
pertimbangan bagi investor untuk lebih cermat menghadapi setiap peristiwa, serta penelitian ini memberikan gambaran mengenai bagaimana perilaku dari masingmasing pelaku pasar dalam bertindak pada saat peristiwa politik.

\section{SIMPULAN}

Tujuan penelitian ini untuk menguji kandungan informasi pada peristiwa politik Pemilihan Gubernur DKI Jakarta Tahun 2017 dengan melihat perbedaan rata-rata abnormal return dan trading volume activity sebelum dan sesudah peristiwa tersebut. Berdasarkan analisis yang dilakukan, disimpulkan tidak terdapat perbedaan rata-rata abnormal returntrading volume activity secara signifikan sebelum dan sesudah Pemilihan Gubernur DKI Jakarta Tahun 2017. Hasil tersebut menunjukkan kandungan informasi peristiwa politik ini tidak cukup dan relevan untuk bisa menggerakkan pelaku pasar dalam berinvestasi dan mengambil keputusan. Pelaku pasar telah bisa memprediksi dan mengantisipasi peristiwa politik tersebut sehingga tidak terburu-buru dalam melakukan keputusan investasi di sekitar peristiwa berlangsung.

Peneliti yang berkeinginan melakukan penelitian sejenis ini, disarankan bisa meneliti peristiwa non ekonomi seperti peristiwa politik lainnya untuk menguji kandungan informasi dan menjelaskan bagaimana rekasi pasar modal pada peristiwa tersebut.Saran untuk calon investor, diharapkan agar lebih bijak, cermat dan berhati-hati menyerap setiap informasi yang dapat menjadi pertimbangan dalam pasar modal. Setiap investor sebaiknyamengamati dengan bijaksana setiap peristiwa yang berlangsung sehingga nantinya keuntungan yang diterima bisa maksimal dan terhindar dari risiko kerugian. 


\section{REFERENSI}

Aktas, H. and Oncu, S. 2006. The Stock Market Reaction to Extreme Events: The Evidence from Turkey. International Research Journal of Finance and Economics, 6 (6): 78-85.

Andansari, Neni Awika. 2016. Pengaruh Return On Equity (Roe), Price Earning Ratio (Per), Total Asset Turn Over (Tato) Dan Price To Book Value (Pbv) Terhadap Return Saham (Studi Kasus Pada Perusahaan Manufaktur Sektor Makanan Dan Minuman Yang Terdaftar Di Bei Periode 2008-2014). Journal Of Accounting, 2 (2).

Bailey, B.A., Heck, J.L. and Wikens, K.A. (2005). International Mutual Fund Performance and Political Risk. Review of Pacific Basin Financial Markets and Policies, 8 (1): 167-184.

Beaulieu, M.C., Cosset, J.C. and Essaddam, N. 2006. Political Uncertainty and Stock Market Returns: Evidence From The 1995 Quebec Referendum. The Canadian Journal Of Economics (Revue Canadienne dEconomique), 39 (2): 621-641.

Bechtel, M.M. (2009). The Political Sources Of Systematic Investment Risk: Lessons From A Consensus Democracy. The Journal of Politics, 71 (2): 661-677.

Bhakti Pratama, I Gede, Sinarwati, Ni Kadek, dan Suryadharmawan, Nyoman Ari. 2015. Reaksi Pasar Modal Indonesia Terhadap Peristiwa Politik (Event Study pada Peristiwa Pelantikan Joko Widodo Sebagai Presiden Republik Indonesia Ke-7). E-Journal S1 Ak Universitas Pendidikan Ganesha, 3 (1).

Bialkowski, Jedrzej, Gottchalk, Katrin, and Wisniewski, Tomasz Piotr. 2006. Stock Market Volatility around National Elections.Research Programme Capital Markets and Finance in the Enlarged Europe.

Bodie, Zvi, Alex Kane, dan Alan J. Marcus. 2005. Investment. $6^{\text {th }}$ edition, Mc. Graw Hill, hal.579-591.

Brown, S. J., and Warner, J. B. (1985). Using daily stock returns: The case of event studies. Journal of Financial Economics, 14(1): 3-31.

Budiman, Agus. 2015. Analisis Perbandingan Average Abnormal Return Dan Average Trading Volume Activity Sebelum Dan Sesudah Peristiwa Pemilihan Umum Presiden Dan Wakil Presiden Tahun 2009 Dan 2014 
(Studi Pada Saham-Saham Lq-45 Di Bursa Efek Indonesia). Management Dynamic Conference. Semarang. 7 Oktober 2015.

Chan, Y. C., and John, W. K. (1996). Political risk and stock price volatility: the case of Hong Kong. Pacific-Basin Finance Journal, 4(2): 259-275.

Chandra, Chan Hengky; Njo Anastasia, dan Gesti Memarista. 2014. "Perbedaan Average Abnormal Return , Average Trading Volume Activity Sebelum dan Sesudah Pemilu di Indonesia”. FINESTA, 2 (1): 114-118.

Chiu, C.L., Chen, C.D., and Tang, W.W. (2005). Political Elections And Foreign Investor Trading In South Korea's Financial Markets. Applied Economics Letters, 12 (11): 673-677.

Chordia, Tarun and Bhaskaran Swaminathan. 2000. Trading Volume and CrossAutocorrelations in Stock Return. The Journal of Finance, 4 (2): 913-935.

Diman Arde, M.Hatta. 2017. Studi Peristiwa Tragedi Sarinah terhadap Pasar Modal Indonesia. E-Jurnal Manajemen Unud, 6 (6), hal.3080-3110.

Foster, George. 1986. Financial Statement Analysis, Second Edition, (New Jersley: Prentice Hall-International Inc), hal.87.

Frey, B.S. and Waldenstrom, D. 2004. Markets Work In War: Worldwar II Reflected In The Zurich And Stockholm Bond Markets. Financial History Review, 11 (1): 51-67.

Ghozali, Imam. 2016. Aplikasi Analisis Multivariate Dengan SPSS. Semarang: Badan Penerbit Universitas Diponegoro.

Harjanto, Havid Deni. 2008. Reaksi Pasar Modal Indonesia Sehubungan Dengan Peristiwa Politik Dalam Negeri Indonesia (Event Study Pada Pengumuman Hasil Pilkada DKI Jakarta Tanggal 16 Agustus 2007). Skripsi Sarjana Jurusan Manajemen Fakultas Ekonomi Universitas Muhammadiyah, Surakarta.

Hartono, Jogiyanto. 2014. Teori Portofolio dan analisis Investasi Edisi Kesembilan. Yogyakarta: BPFE-Yogyakarta.

Henderson, G.V. Jr. 1990. Problems and Solutions in Conducting Event Studies. Journal of Risk and Insurance, 57 (2): 282-306.

Husnan, Suad. 2001, Dasar-dasar Teori Portofolio dan Analisis Sekuritas. Yogyakarta. Penerbit: UPP AMP YKPN. 
Ida Ayu Nirma Prameswari dan Made Gede Wirakusuma. Analisis...

Hutami, Rizkia Nur. 2014. Abnormal Return Dan Trading Volume Activity Sebelum Dan Setelah PemilihanPresiden Secara Langsung 9 Juli 2014(Studi Kasus Pada Saham LQ-45). Skripsi Sarjana pada Fakultas Ekonomika dan Bisnis Universitas Diponegoro, Semarang.

Ismail and Suhardjo. 2001. The Impact of Domestic Political Event on an Emerging Stock Market: The case of Indonesia. Proceeding of the Asia Pacific Management Conference, hal. 23-262.

Jatmiko, Dadang Prasetyo, Manahov, Viktor, Obiosa, Nnamdi. 2014. Does capital market reaction to non-economic factors generate abnormal returns?. Journal of Investment Management and Financial Innovations, 11 (4). Inter 12

Khalid, A. M., \& Rajaguru, G. 2010. The impact of political events on financial market volatility: Evidence using a Markov Switching process. Working Paper The Globalisation and Development Centre, Bond University, Austraila, 43.

Latifah, Siti. 2017. Perbedaan Trading Volume Activity (TVA) Dan Harga Saham Saat Pelantikan Menteri Esdm Ignasius Jonan Tahun 2016 (Pada Saham Lq45 Periode Agustus 2016 - Januari 2017). Jurnal Akuntansi.

Levine, R. and Zervos, S. 1998. "Stock Markets, Banks And Economic Growth”, American Economic Review, 88 (3): 537-558.

Manzoor, H. 2013. Impact of pak-US relationship news on KSE-100 Index. Basic Research Journal of Business Management and Accounts, 2 (2): 1-24. Inter 15

Martalena dan Malinda, Maya. 2011. Pengantar Pasar Modal. Bandung : Andi Yogyakarta.

Melati, Dewi Arum, Saryadi, Dan Widiartanto. 2014. Analisis Reaksi Pasar Modal Atas Peristiwa Pemilihan Presiden 9 Juli 2014 (Event Study Pada Indeks Saham LQ-45). Junal Ilmiah Universitas Diponegoro.

Nazir, Mian Sajid, Younus, Hassan, Kaleem, Ahmad, Anwar, Zeshan. 2014. Impact of Political Events on Stock Market Returns: Empirical Evidence From Pakistan. Journal of Economic and Administrative Sciences 30 (1): 60-78. Inter 16 
Pamungkas, Aryo, Suhadak, dan Endang NP, MG Wi. 2015. Pengaruh Pemilu Presiden Indonesia Tahun 2014 Terhadap Abnormal Return dan Trading Volume Activity (Studi Pada Perusahaan Pada Perusahaan Yang Tercatat Sebagai Anggota Indeks Kompas 100). Jurnal Administrasi Bisnis Universitas Brawijaya, 20 (1). Hal.1-9.

Permana, Henry Tirta. 2013. Perbedaan Abnormal Return pada Sektor Keuangan Sebelum dan Sesudah Peristiwa Pilkada Gubernur DKI Jakarta 20 September 2012. Jurnal Ilmiah Mahasiswa Universitas Surabaya, 2 (1): 19.

Permata Sari, Ni Putu Tila. 2017. Analisis Komparatif Saham LQ45 Sebelum dan Sesudah Pilpres Amerika Serikat 2016. Jurnal Ilmiah Mahasiswa Universitas Pendidikan Ganesha, 7 (1).

Peterson, Pamela P. 1989. Event Studies: A Review of Issues and Methodology. Quarterly Journal of Business and Economics. Summer. (28), hal.36-66.

Purba, Fransisko dan Handayani, Siti Ragil. 2017. Analisis Perbedaan Reaksi Pasar Modal Indonesia Sebelum dan Sesudah Peristiwa Non Ekonomi (Studi pada Peristiwa Politik Pilkada DKI Jakarta 2017 Putaran Kedua). Jurnal Administrasi Bisnis Universitas Brawijaya, 51 (1): 115-123.

Purwana Taunay, Edward Gagah. 2013. Pasar Modal Indonesia. Majalah Ilmiah Universitas Pandanaran, 11 (26).

Samsul, Mohamad. 2006. Pasar Modal dan Manajemen Portofolio. Jakarta: Erlangga.

Santoso, Heri dan Sri Artini, Luh Gede. 2015. Reaksi Pasar Modal Indonesia Terhadap Pemilu Legislatif 2014 Pada Indeks Lq45 di BEI. E-Jurnal Akuntansi Universitas Udayana, 4 (9): 2647-2674.

Saputra, Indra. 2016. Analisis Perbedaan Rata-Rata Trading Volume Activity Saham Sebelum Dan Sesudah Pemilu Presiden Dan Wakil Presiden Tahun 2014 (Event Study Pada Saham LQ-45 Di Bursa Efek Indonesia Periode 29 Juni - 19 Juli 2014). Jurnal Ekonomi dan Bisnis, 9 (1): 76-86.

Simanjuntak, Suhermanto. 2017. Analisis Perbandingan Average Abnormal Return dan Average Trading Volume Activity Sebelum dan Sesudah Pilkada DKI Jakarta Tahun 2017 (Studi Empiris pada Perusahaan Anggota Indeks LQ-45 di Bursa Efek Indonesia. Skripsi Sarjana pada Fakultas Ekonomi dan Bisnis Universitas Lampung, Bandar Lampung. 
Ida Ayu Nirma Prameswari dan Made Gede Wirakusuma. Analisis...

Sumiyana. 2007. Noise atau Kedatangan Informasi: Sebuah Fenomena Spesifik Perilaku Harga Saham Dipasar Modal Indonesia. JurnalEkonomi dan Bisnis Indonesia, 22 (3): 292-318.

Sureni Yuniarthi, Ni Nengah. 2016. Reaksi Pasar Modal Terhadap Pencalonan Jokowi Menjadi Presiden Republik Indonesia. E-Jurnal Akuntansi Universitas Udayana, 16 (2): 951-977.

Trisnadi, Margareta Maria. 2016. Pengujian Anomali Pasar: Day of The Week Effect pada Saham LQ-45 Di Bursa Efek Indonesia. E-Jurnal Manajemen, 5 (6): 3794-3820.

Tobing, Manuella L. 2012. Analisis Hubungan Return On Assets, Financial Leverage, Firm Size, dan Umur Perusahaan Dengan Underpricing Saham pada Perusahaan Manufaktur Di Bursa Efek Indonesia. Skripsi Sarjana pada Fakultas Ekonomi Universitas Sumatera Utara, Medan.

Wardhani, Laksmi Swastika. 2012. Reaksi Pasar Modal Indonesia Terhadap Peristiwa Pemilihan Gubernur DKI Jakarta Putaran II 2012 (Event Study pada Saham Anggota Indeks Kompas 100). Jurnal Ilmiah Mahasiswa Fakultas Ekonomi dan Bisnis Universitas Brawijaya, 1 (1): 2-12.

Watts, Ross L. and Zimmerman, Jerold L. 1986. Positive Accounting Theory. (New Jersey: Prentice Hall, Inc), hal.221-223.

Widi Hartawan, I Made, Pradana Adiputra, I Made, Surya Darmawan, Nyoman Ari. 2015. Analisis Perubahan Volume Perdagangan Saham Dan Abnormal Return Sebelum Dan Sesudah Pemilu Legislatif 9 April 2014 (Event StudyPada Sektor-Sektor Industri Di Bursa Efek Indonesia). Jurnal Akuntansi Program S1, 3 (1).

Widianingsih, Tenti dan Wijaya, Chandra. 2014. Analisis Pengaruh Pelaksanaan Pemilu Legislatif dan Pemilu Presiden Tahun 2004, 2009, dan 2014 terhadap Return Indeks Sektoral dan IHSG di Bursa Efek Indonesia. Skripsi Sarjana pada Fakultas Ekonomi Universitas Indonesia, Jakarta 